\title{
BIBLIOTEKI WYDZIALU PRAWA I NAUK SPOŁECZNO-EKONOMICZNYCH KUL W OKRESIE II RZECZPOSPOLITEJ
}

\begin{abstract}
Wstęp
Katolicki Uniwersytet Lubelski w Lublinie powstał w 1918 r., dzięki współpracy wielu osób, w tym: inicjatora ks. Idziego Radziszewskiego, fundatorów: Karola Jaroszyńskiego i Franciszka Skąpskiego, biskupów polskich oraz wizytatora Stolicy Apostolskiej Achillesa Rattiego ${ }^{1}$. Był to czas wyjątkowy. Polska po 123 latach niewoli odzyskała niepodległość. Potrzeba odbudowy wszystkich dziedzin życia narodowego poprzez m.in. tworzenie ośrodków naukowych i kształcenie młodzieży: osób duchownych i świeckich była oczywista.

Pomimo trudności organizacyjnych, w pierwszym roku akademickim 1918/1919 na Uniwersytecie Lubelskim uruchomiono cztery wydziały: Teologiczny, Prawa Kanonicznego i Nauk Moralnych, Prawa i Nauk Społeczno-Ekonomicznych oraz Nauk Humanistycznych. Funkcjonowały one do czasu wybuchu II wojny światowej ${ }^{2}$. Środowisko naukowe nowo powstałej uczelni liczyło w 1918 r. 25 osób, a w 1938 r. miało już 69 pracowników ${ }^{3}$.

W ramach Wydziału Prawa i Nauk Społeczno-Ekonomicznych istniały dwie grupy: prawna i ekonomiczno-społeczna. Należy podkreślić, że w okresie II Rzeczypospolitej wydział ten był najprężniejszym ośrodkiem katolicyzmu społecz-

\footnotetext{
* Monika Nowakowska - dr historii; kustosz w Bibliotece Instytutu Ekonomii i Zarządzania KUL; e-mail: mnowak@kul.pl

${ }^{1}$ G. Karolewicz, Geneza Katolickiego Uniwersytetu Lubelskiego, w: Katolicki Uniwersytet Lubelski. Wybrane zagadnienia z dziejów Uczelni, red. G. Karolewicz, M. Zahajkiewicz, Z. Zieliński, Lublin 1992, s. 69.

${ }^{2}$ A. Wojtkowski, Katolicki Uniwersytet Lubelski 1918-1944, w: Księga Jubileuszowa 50-lecia Katolickiego Uniwersytetu Lubelskiego, Lublin 1969, s. 32-33.

${ }^{3}$ G. Karolewicz, Środowisko naukowe KUL w okresie międzywojennym, w: Katolicki Uniwersytet Lubelski. Wybrane zagadnienia z dziejów Uczelni, red. G. Karolewicz, M. Zahajkiewicz, Z. Zieliński, Lublin 1992, s. 144.
} 


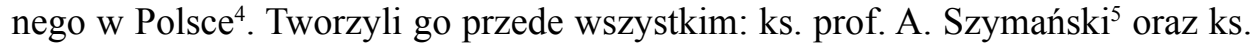
prof. A. Wóycicki ${ }^{6}$. W tym czasie ks. prof. A. Szymańskiego, autora ponad 280 publikacji, uważano za najwybitniejszego reprezentanta nauki społecznej Kościo$\mathfrak{ł a}^{7}$. Jego Polityka społeczna była pierwszym podręcznikiem polityki społecznej, napisanym w duchu katolicyzmu. Z tym kierunkiem związani byli także ekonomiści i prawnicy Wydziału Prawa i Nauk Społeczno-Ekonomicznych ${ }^{8}$. Ekonomię reprezentował prof. L. Górski ${ }^{9}$, natomiast prawo: prof. I. Czuma ${ }^{10}$ i prof. Cz. Strzeszewski ${ }^{11}$.

Wraz z powołaniem uniwersytetu do życia, konieczne było zapewnienie odpowiedniej bazy dydaktycznej w postaci książek i czasopism dla studentów i pracowników naukowych. Rolę tę pełniła Biblioteka Uniwersytecka, zlokalizowana w gmachu byłego klasztoru bernardynów przy ulicy Dolnej Panny Marii, jak również biblioteki poszczególnych seminariów, skupionych przy katedrach, znajdujących się w gmachu KUL przy Alejach Racławickich ${ }^{12}$.

Celem artykułu jest przedstawienie specyfiki funkcjonowania bibliotek istniejących na Wydziale Prawa i Nauk Społeczno-Ekonomicznych Uniwersytetu Lubelskiego (od 1928 r. Katolickiego Uniwersytetu Lubelskiego), charakterystyki personelu i gromadzonego księgozbioru w okresie II Rzeczypospolitej.

${ }^{4}$ G. Karolewicz, Nauczyciele akademiccy Katolickiego Uniwersytetu Lubelskiego w okresie międzywojennym, t. 1, Lublin 1996, s. 186.

${ }^{5}$ Antoni Szymański (1881-1942) - ks. prof. polityki społecznej i ekonomicznej KUL (19181939); dziekan Wydziału Prawa Kanonicznego (1920/1921); prodziekan tego Wydziału (1921/1922); dziekan Wydziału Prawa i Nauk Społeczno-Ekonomicznych (1931-1933), wicerektor (1922-1926); rektor (1933-1939). Zob. G. Karolewicz, Nauczyciele akademiccy Katolickiego Uniwersytetu Lubelskiego w okresie międzywojennym, t. 2, Biogramy, Lublin 1996, s. 222-224; Cz. Strzeszewski, Ks. Antoni Szymański jako profesor i rektor Katolickiego Uniwersytetu Lubelskiego, „Zeszyty Naukowe KUL”, 5 (1962) nr 3 (19), s. 103-114.

${ }^{6}$ Aleksander Wóycicki (1878-1954) - ks. prof. historii, socjologii, etyki społecznej na trzech Wydziałach KUL: Prawa Kanonicznego, Prawa i Nauk Społeczno-Ekonomicznych i Nauk Humanistycznych (1918-1924). Zob. Karolewicz, Nauczyciele akademiccy, t. 2, s. 239-241.

${ }^{7}$ Karolewicz, Nauczyciele akademiccy, t. 1, s. 187.

${ }^{8}$ M. Bogusz, A. Miszczuk, Lubelskie akademickie środowisko ekonomistów w okresie międzywojennym, „Chrześcijanin w Świecie”, 19 (1987) nr 4 (163), s. 16-17.

${ }^{9}$ Ludwik Górski (1894-1945) - prof. ekonomii i historii gospodarczej na Wydziale Prawa i Nauk Społeczno-Ekonomicznych (1924-1939) oraz na Wydziale Nauk Humanistycznych KUL (1925-1933). Pełnił funkcję dziekana i prodziekana Wydziału Prawa i Nauk Społeczno-Ekonomicznych KUL (1928-1930). Zob. Karolewicz, Nauczyciele akademiccy, t. 2, s. 74-75.

${ }^{10}$ Ignacy Czuma (1891-1963) - prof. skarbowości na Wydziale Prawa i Nauk Społeczno-Ekonomicznym KUL (1924-1939); pełnił funkcję prodziekana (1924-1926) i dziekana (1926-1928) na tym wydziale; w roku akad. 1938/39 był prorektorem KUL. Zob. Karolewicz, Nauczyciele akademiccy, t. 2, s. 39-41.

${ }^{11}$ Czesław Strzeszewski (1903-1999) - w latach 1933-1937 wykładał historię gospodarczą i politykę ekonomiczną na Wydziale Prawa i Nauk Społeczno-Ekonomicznym KUL oraz na Wydziale Nauk Humanistycznych (1933-1935). Zob. G. Karolewicz, Nauczyciele akademiccy, t. 2, s. 215-217.

${ }^{12}$ Spis wyktadów i wykaz instytucyj uniwersyteckich. Pótrocze zimowe 1918/1919, Lublin 1919, s. 33 . 


\section{Struktura}

W ramach Wydziału Prawa i Nauk Społeczno-Ekonomicznych nie istniała jedna biblioteka wydziałowa, lecz księgozbiory były tworzone przy poszczególnych seminariach. Seminarium było wówczas ściśle związane z katedrą profesora. To oni tworzyli biblioteki seminaryjne. W omawianym okresie, w ramach Bibliotek Wydziału Nauk Prawa i Nauk Społeczno-Ekonomicznych funkcjonowały trzy biblioteki sekcyjne: prawna, ekonomiczna i polityki społecznej. Na określenie tych bibliotek używano następujących terminów: Biblioteka Seminarium Prawnego, Biblioteka Seminarium Ekonomicznego (Biblioteka Seminarium Ekonomiczno-Statystycznego) i Biblioteka Seminarium Polityki Społecznej ${ }^{13}$.

Biblioteka Seminarium Polityki Społecznej powstała około 1924 r., kiedy to nastąpiło wydzielenie publikacji z zakresu polityki społecznej z inwentarza księgozbioru nauk społecznych ${ }^{14}$. Do tego czasu, biblioteka istniała w ramach Biblioteki Seminarium Ekonomiczno-Politycznego. Jej twórcą był ks. prof. A. Szymański ${ }^{15}$.

Należy podkreślić, że w ramach biblioteki prawnej funkcjonowały odrębne księgozbiory następujących seminariów: prawa, prawa rzymskiego i prawa kanonicznego ${ }^{16}$. W roku akademickim 1931/1932 zorganizowano Bibliotekę Seminarium Prawa Kościelnego ${ }^{17}$.

$\mathrm{Na}$ koniec sierpnia 1939 r. księgozbiory były pogrupowane według następujących seminariów: historyczno-prawnego, prawa rzymskiego, ogólno-prawnego, prawa publicznego, prawa sądowego, ekonomicznego i polityki społecznej ${ }^{18}$. $\mathrm{W}$ tym czasie na wszystkich wydziałach uniwersytetu istniało 16 bibliotek seminaryjnych $^{19}$.

\section{Personel}

W pierwszych latach organizacji bibliotek seminaryjnych nie było stanowiska bibliotekarza. Odpowiedzialność nad księgozbiorem spoczywała na profesorach, którzy pełnili funkcję referenta do spraw bibliotek ${ }^{20}$. W 1920 r. rolę tę sprawowali

${ }^{13}$ Archiwum Uniwersyteckie Katolickiego Uniwersytetu Lubelskiego Jana Pawła II (dalej: AU KUL). Biblioteki Zakładowe Wydziału Prawa i Nauk Społeczno-Ekonomicznych 1920-1939.

${ }^{14}$ AU KUL, Katalog Seminarium Polityki Społecznej 12.01.1924-21.05.1933.

${ }^{15}$ AU KUL, Biblioteki Zakładowe Wydziału Prawa i Nauk Społeczno-Ekonomicznych 19201939.

${ }^{16}$ AU KUL, Biblioteki Zakładowe Wydziału Prawa i Nauk Społeczno-Ekonomicznych 19201939. Instrukcja dla bibliotekarza Seminarium Wydziału Prawa i Nauk Społeczno-Ekonomicznych.

${ }^{17}$ AU KUL, Biblioteki Zakładowe Wydziału Prawa i Nauk Społeczno-Ekonomicznych 19201939. Sprawozdanie z działalności kierownictwa Biblioteki Seminarium Prawno-Ekonomicznego KUL w okresie od 1 lipca 1931 do 15 czerwca 1932.

${ }^{18}$ AU KUL, Kancelaria Rektorska. Biblioteki Zakładowe. Biblioteki Zakładów Naukowych. Wydział Prawa i Nauk Społeczno-Ekonomicznych 1946-1950.

${ }^{19}$ D. Dzierzkowska, Biblioteka Główna Katolickiego Uniwersytetu Lubelskiego 1918-1939, „Archiwa, Biblioteki i Muzea Kościelne” (dalej: ABMK), 8 (1964) s. 203.

${ }^{20}$ AU KUL, Biblioteki Zakładowe Wydziału Prawa i Nauk Społeczno-Ekonomicznych 19201939. 
- dla seminariów prawniczych: prof. T. Hilarowicz ${ }^{21}$, a dla Biblioteki Seminarium Ekonomiczno-Politycznego: ks. prof. A. Szymański ${ }^{22}$. Pomoc w zakresie nadzoru nad księgozbiorem sprawowali, zapewnie zleconą przez profesora katedry: asystenci i studenci. $Z$ czasem pojawiło się stanowisko bibliotekarza, który zarządzał zgromadzonym księgozbiorem. W latach 30 . XX w. funkcje te pełnili asystenci i studenci, jak np. Aleksander Kunickii ${ }^{23}$, Konstanty Turowskii ${ }^{24}$ czy Kazimierz Osuchowski ${ }^{25}$.

Na podstawie zachowanej Instrukcji dla bibliotekarza Seminarium Wydziatu Prawa i Nauk Spoleczno-Ekonomicznych ${ }^{26}$ wiadomo, że bibliotekarz podlegał bezpośrednio dziekanowi wydziału lub oddelegowanemu profesorowi. Za swoją pracę (pięć godzin dziennie) otrzymywał miesięcznie wynagrodzenie. W zarządzaniu bibliotekami pomagali mu studenci-stypendyści, którzy również otrzymywali pensję. Prawdopodobnie, w pierwszych latach funkcjonowania Wydziału początkowo był jeden bibliotekarz, który odpowiadał za wszystkie biblioteki seminaryjne. Potwierdza to zachowana dokumentacja. Student Konstanty Turowski od 1.09.1930 r. do 30.06.1933 r. kierował Biblioteką Wydziału Prawa i Nauk Społeczno-Ekonomicznych oraz sprawował nadzór nad stypendystami, opiekującymi się poszczególnymi bibliotekami seminaryjnym ${ }^{27}$.

W późniejszych latach powoływano bibliotekarzy do każdej sekcji oddzielnie. Dla przykładu, w roku akademickim 1935/1936 bibliotekarzem księgozbioru Seminarium Prawnego był Aleksander Kunicki. W pracy pomagało mu 11

${ }^{21}$ Tadeusz Hilarowicz (1887-1958) - prof. prawa; w latach 1918-1920 pełnił funkcję zastępcy profesora na Wydziale Prawa i Nauk Społeczno-Ekonomicznych oraz Prawa Kanonicznego i na Wydziale Nauk Humanistycznych (1918/1919). Zob. Karolewicz, Nauczyciele akademiccy, t. 2, s. 81-83. Prof. T. Hilarowicz był w roku akad. 1918/1919 członkiem Komisji Bibliotecznej. Zob. Spis wykładów i wykaz instytucyj uniwersyteckich. Pótrocze zimowe 1918/1919, s. 40.

${ }^{22}$ Por. przypis 5.

${ }^{23}$ Aleksander Kunicki (1908-1984) - w latach 1934-1937 asystent na Wydziale Prawa i Nauk Społeczno-Ekonomicznych KUL przy Katedrze Prawa Cywilnego. Zob. Karolewicz, Nauczyciele akademiccy, t. 2, s. 118-119.

${ }^{24}$ Konstanty Turowski (1907-1983) - w latach 1929-1933 studiował ekonomię na Wydziale Prawa i Nauk Społeczno-Ekonomicznych KUL. Zob. AU KUL, sygn. 1148 B, Akta osobowe: Konstanty Turowski.

${ }^{25}$ Kazimierz Osuchowski (1915-1944) - w latach 1933-1938 studiował prawo na Wydziale Prawa i Nauk Społeczno-Ekonomicznego KUL; od roku akad. 1937/1938 był młodszym asystentem, a następnie starszym asystentem przy katedrze Polityki Społecznej, kierowanej przez ks. prof. A. Szymańskiego. Zob. AU KUL, sygn. PE 3114, Akta osobowe: Kazimierz Osuchowski; Karolewicz, Nauczyciele akademiccy, t. 2, s. 156-157.

${ }^{26}$ AU KUL, Biblioteki Zakładowe Wydziału Prawa i Nauk Społeczno-Ekonomicznych 19201939. Instrukcja dla bibliotekarza Seminarium Wydziału Prawa i Nauk Społeczno-Ekonomicznych.

${ }^{27}$ AU KUL, sygn. 1148 B, Akta osobowe: Konstanty Turowski. 
stypendystów (m.in. Jan Amerek $\left.{ }^{28}\right)^{29}$. W następnym roku akademickim funkcję bibliotekarza nadal pełnił Aleksander Kunicki, a liczba stypendystów tej biblioteki wzrosła do 13 osób. W kolejnych latach nadzór nad Biblioteką Seminarium Prawnego sprawowali m.in. Witold Baliński ${ }^{30}$, Stefan Pyśniak ${ }^{31}$. W roku akademickim 1936/1937 bibliotekarzem sekcji ekonomicznej był starszy asystent Jerzy Malczewski ${ }^{32}$. W kolejnym roku akademickim funkcję tę pełnił Stefan Pyśniak, który następnie zajmował się biblioteką prawnicząa ${ }^{33}$ W latach 1936-1939 Bibliotekę Seminarium Polityki Społecznej prowadził asystent Kazimierz Osuchowski. W pracy pomagał mu stypendysta, który na początku tego roku akademickiego dyżurował samodzielnie, gdyż bibliotekarz został powołany na zgrupowanie wojskowe ${ }^{34}$.

W większości przypadków stypendyści wywiązywali się ze swoich obowiązków. Dla przykładu, w świetle sprawozdania za rok akademicki 1932/1933, studenci Biblioteki Seminarium Polityki Społecznej pracowali sumiennie, jedynie dwa tygodnie przed egzaminami opuszczali swoje dyżury. Z kolei w roku akademickim 1935/1936 dwaj dyżurni Biblioteki Seminarium Prawa (m.in. J. Amerek), pomimo upomnień bibliotekarza, nie stosowali się do regulaminów funkcjonowania jednostki. Ich zaniedbania (opuszczanie dyżurów, ignorowanie uwag bibliotekarza) doprowadziły do braków książek i nieporządków w bibliotece ${ }^{35}$.

${ }^{28}$ Jan Amerek (1908-1940) - absolwent prawa Wydziału Prawa i Nauk Społeczno-Ekonomicznego KUL z 1936 roku. Zamordowany w 1940 r. w Katyniu. Tablica pamiątkowa znajduje się w Kościele Akademickim KUL. Zob. AU KUL, sygn. PE 2966, Akta osobowe: Jan Amerek.

${ }^{29}$ AU KUL, Biblioteki Zakładowe Wydziału Prawa i Nauk Społeczno-Ekonomicznych 19201939.

${ }^{30}$ Witold Baliński - studiował prawo na Wydziale Prawa i Nauk Społeczno-Ekonomicznych KUL w latach 1933-1937. Od 01.05.1936 do 01.04.1938 r. pełnił funkcję asystenta przy Katedrze Prawa Politycznego i Ogólnej Nauki o Państwie. Zob. AU KUL, sygn. PE 3032, Akta osobowe: Witold Baliński; A. Stanowski, Spis wyktadowców 1918-1939, w: Księga Jubileuszowa 50-lecia Katolickiego Uniwersytetu Lubelskiego, Lublin 1969, s. 113.

${ }^{31}$ Stefan Pyśniak - studia na sekcji ekonomicznej Wydziału Prawa i Nauk Społeczno-Ekonomicznych KUL rozpoczął w roku akad. 1936/1937 i kontynuował po wojnie. Zob. AU KUL, sygn. PNSE 4165, Akta osobowe: Stefan Pyśniak.

32 Jerzy Malczewski - studiował prawo na Wydziale Prawa i Nauk Społeczno-Ekonomicznych KUL w latach 1932-1936. Zob. AU KUL, sygn. PE 2804, Akta osobowe: Jerzy Malczewski; Sktad osobowy. Spis wyktadów i instytucji Katolickiego Uniwersytetu Lubelskiego w roku akad. 1936/1937, Lublin [1936], s. 47.

${ }^{33}$ Skład osobowy. Spis wykładów i instytucji Katolickiego Uniwersytetu Lubelskiego w roku akad. 1937/1938, Lublin [1937], s. 47; Sktad osobowy. Spis wyktadów i instytucji Katolickiego Uniwersytetu Lubelskiego w roku akad. 1938/1939, Lublin [1938], s. 47.

${ }^{34}$ Skład osobowy. Spis wykładów i instytucji Katolickiego Uniwersytetu Lubelskiego w roku akad. 1936/1937, s. 47; Skład osobowy. Spis wyktadów i instytucji Katolickiego Uniwersytetu Lubelskiego w roku akad. 1938/1939, s. 47; AU KUL, Biblioteki Zakładowe Wydziału Prawa i Nauk Społeczno-Ekonomicznych 1920-1939. Sprawozdanie z Biblioteki Seminarium Polityki Społecznej KUL za czas od 25.06.1938 do 25.01.1939.

${ }^{35}$ AU KUL, Biblioteki Zakładowe Wydziału Prawa i Nauk Społeczno-Ekonomicznych 19201939. Pismo Aleksandra Kunickiego do Dziekana Wydziału Prawa i Nauk Społeczno-Ekonomicznych KUL z dnia 5 maja 1936 r. 
W następnym roku akademickim stypendyści tej biblioteki opuścili tylko 8 godzin dyżurów ${ }^{36}$.

\section{Księgozbiory}

Zasób bibliotek seminaryjnych Wydziału Prawa i Nauk Społeczno-Ekonomicznych stanowiły księgozbiory pozyskiwane drogą zakupów i darów. Jednak wobec trudności finansowych Uczelni, biblioteki miały bardzo ograniczony budżet. Sytuację ratował przyznany przez Rektora KUL ks. Cz. Sokołowskiego (1924-1925) stały fundusz - uzyskany z opłat studenckich ${ }^{37}$. Pod koniec lat 30. XX w. największe źródło finansowania otrzymywały właśnie biblioteki tego wydziału. Dla przykładu w roku akademickim 1936/1937 biblioteki seminaryjne na Wydziale Prawa i Nauk Społeczno-Ekonomicznych otrzymały ponad $8.000 \mathrm{zk}$, na Wydziale Teologicznym odpowiednio - około 1.300 zł, na Wydziale Kanonicznym - ponad $450 \mathrm{zt}$ i na Wydziale Humanistycznym $3.000 \mathrm{zt}^{38}$. W kolejnym roku akademickim 1937/1938 Wydział prawniczy wystawił rachunki za książki i czasopisma na kwotę ponad $6.000 \mathrm{zt}^{39}$.

W latach 1920-1938 Biblioteka Główna Uniwersytetu Lubelskiego (od 1928 r. Katolickiego Uniwersytetu Lubelskiego) przekazała Bibliotece Seminarium Statystyczno-Ekonomicznego ${ }^{40}$ i Seminarium Polityki Społecznej ${ }^{41}$ zbiory liczące kilka tysięcy woluminów: druków zwartych i wydawnictw o charakterze ciągłym. W latach 1919-1927 oraz 1932-1939 Biblioteka Główna mogła przekazywać bibliotekom seminaryjnym książki pochodzące również z egzemplarza obowiązkowego od wydawców ${ }^{42}$.

Księgozbiór był również powiększany dzięki darowiznom osób fizycznych, przede wszystkim profesorów Wydziału. Na szczególne wyróżnienie zasługuje dar ks. prof. A. Szymańskiego, który ofiarował swój księgozbiór, liczący ponad 2.000 książek (głównie z zakresu katolickiej nauki społecznej i historii społecznej) - Bibliotece Seminarium Polityki Społecznej ${ }^{43}$. Zasób bibliotek seminaryjnych wzbogaciły prace przekazane przez profesorów: S. Ptaszyckiego ${ }^{44}$,

${ }^{36}$ AU KUL, Biblioteki Zakładowe Wydziału Prawa i Nauk Społeczno-Ekonomicznych 19201939. Sprawozdanie z działalności Biblioteki Seminarium Ekonomicznego za okres od 1 sierpnia 1935 do 15 czerwca 1936.

${ }^{37}$ Dzierzkowska, Biblioteka Główna Katolickiego Uniwersytetu Lubelskiego, s. 203.

${ }^{38}$ Sprawozdanie ze stanu KUL w roku akademickim 1936/37, Lublin [1937], s. 21.

${ }^{39}$ Sprawozdanie ze stanu KUL w roku akademickim 1937/38, Lublin [1938], s. 20.

${ }^{40}$ AU KUL, Katalog książek oddanych do Biblioteki Seminarium Statystyczno-Ekonomicznego 4.05.1920-18.11.1938.

${ }^{41}$ AU KUL, Katalog Seminarium Polityki Społecznej 12.01.1924-21.05.1933.

${ }^{42}$ Sprawozdanie ze stanu KUL w roku akademickim 1935/36, Lublin [1936], s. 16; Dzierzkowska, Biblioteka Główna Katolickiego Uniwersytetu Lubelskiego, s. 215-216.

${ }^{43}$ Pismo do Senatu KUL z dnia 19 czerwca 1930 r., w którym ks. prof. A. Szymański ofiarował całą swoją bibliotekę Katolickiemu Uniwersytetowi Lubelskiemu. Zob. AU KUL, sygn. A-55, Akta osobowe: ks. prof. Antoni Szymański.

${ }^{44}$ Stanisław Ptaszycki (1853-1933) - w latach 1918-1926 prof. nauk pomocniczych historii i historii średniowiecznej na Wydziale Teologicznym i na Wydziale Nauk Humanistycznych KUL; 
I. Czumę ${ }^{45}$, W. Krzyżanowskiego ${ }^{46}$, ks. H. Insadowskiego ${ }^{47}$, ks. J. Wiślickiego ${ }^{48}$, Z. Papierkowskiego ${ }^{49}$ oraz R. Longchamps'a de Berier $^{50}$. Z kolei Międzynarodowe Biuro Pracy przy Lidze Narodów podarowało publikacje z cyklu Revue Internationale du Travail ${ }^{51}$.

Nie zachowały się dane dotyczące szczegółowych zestawień wpływów książek do bibliotek seminaryjnych dla lat 20. XX w. Dopiero kolejna dekada przynosi niepełne informacje na ten temat. Dla przykładu, w roku akademickim 1931/1932 do biblioteki ekonomicznej wpisano 157 książek, z czego 103 (ok. 66\%) - stanowiły książki zakupione, a 54 - darowane (w tym 24 publikacje z Biblioteki Głównej). Biblioteka prawnicza wzbogaciła się o 140 nowe publikacje, w tym 95 (ok. 68\%) stanowiły książki zakupione ${ }^{52}$.

Poniższa tabela przedstawia zachowane dane dotyczące zasobu księgozbiorów dla poszczególnych bibliotek seminaryjnych Wydziału Prawa i Nauk Społeczno-Ekonomicznych w latach 30. XX w.

w latach 1918-1923 prowadził również zajęcia na Wydziale Prawa Kanonicznego; w roku akad. 1921/1922 wicerektor KUL, a w roku 1918/1919 dziekan Wydziału Nauk Humanistycznych i dyrektor Biblioteki Uniwersyteckiej. Karolewicz, Nauczyciele akademiccy, t. 2, s. 182-185.

${ }^{45}$ Por. przypis 10.

${ }^{46}$ Witold Krzyżanowski (1897-1972) - w latach 1923-1939 prof. geografii gospodarczej i historii handlu na Wydziale Prawa i Nauk Społeczno-Ekonomicznym KUL; pełnił funkcję prodziekana (1930-1931 i 1935-1936) i dziekana (1933-1935) wydziału. Zob. Karolewicz, Nauczyciele akademiccy, t. 2, s. 114-116.

${ }^{47}$ Henryk Insadowski (1888-1946) - ks. prof. prawa rzymskiego m.in. na Wydziale Prawa i Nauk Społeczno-Ekonomicznym KUL (1932-1939); pełnił funkcję prodziekana Wydziału Prawa Kanonicznego (1935-1937) i dziekana tego wydziału (1937-1939), a także dyrektora Biblioteki Uniwersyteckiej (1924-1939). Zob. Karolewicz, Nauczyciele akademiccy, t. 2, s. 88-89.

48 Jan Wiślicki (1879-1944) - ks. prof. na Wydziale Prawa i Nauk Społeczno-Ekonomicznym KUL (1922-1939); dziekan tego wydziału (1929-1931 i 1935-1937) i prodziekan (1934/35 i 19371939). Zob. Karolewicz, Nauczyciele akademiccy, t. 2, s. 233-234.

${ }^{49}$ Zdzisław Papierkowski (1903-1980) - prof. prawa na Wydziale Prawa i Nauk Społeczno-Ekonomicznym KUL (1931-1939). Zob. Karolewicz, Nauczyciele akademiccy, t. 2, s. 161-163.

${ }^{50}$ Roman Longchamps de Berier (1883-1941) - prof. prawa cywilnego na Wydziale Prawa i Nauk Społeczno-Ekonomicznych KUL (1920-1939). Pełnił funkcję prodziekana tegoż wydziału (1920-1922, 1923/1924) i dziekana (1922/1923). Zob. Karolewicz, Nauczyciele akademiccy, t. 2, s. $130-132$.

${ }^{51}$ AU KUL, Biblioteki Zakładowe Wydziału Prawa i Nauk Społeczno-Ekonomicznych 19201939.

${ }^{52}$ AU KUL, Biblioteki Zakładowe Wydziału Prawa i Nauk Społeczno-Ekonomicznych 19201939. Sprawozdanie z działalności kierownictwa Biblioteki Seminarium Prawno-Ekonomicznego KUL w okresie od 1 lipca 1931 do 15 czerwca 1932. 
Tab. 1. Zestawienie liczby książek bibliotek seminaryjnych Wydziału Prawa i Nauk Społeczno-Ekonomicznych w latach 30 . XX wieku ${ }^{53}$.

\begin{tabular}{|l|c|c|c|}
\hline Rok & $\begin{array}{l}\text { Biblioteka Seminarium } \\
\text { Prawnego }\end{array}$ & $\begin{array}{l}\text { Biblioteka Seminarium } \\
\text { Ekonomicznego }\end{array}$ & $\begin{array}{l}\text { Biblioteka Seminarium } \\
\text { Polityki Spolecznej }\end{array}$ \\
\hline 1930 & $487(450)^{*}$ & $438(419)^{*}$ & b. d. \\
\hline 1931 & 717 & 770 & b. d. \\
\hline 1932 & 857 & 927 & 600 \\
\hline 1933 & 1016 & 1188 & 2550 \\
\hline 1934 & b. d. & b. d. & b. d. \\
\hline 1935 & b. d. & b. d. & b. d. \\
\hline 1936 & 1814 & b. d. & b. d. \\
\hline 1937 & 1972 & 1838 & b. d. \\
\hline 1938 & b.d. & b. d. & 4106 \\
\hline 1939 & 3034 & 2226 & . \\
\hline
\end{tabular}

* stan wg książki inwentarzowej, w nawiasie - stan faktyczny

** dane na podstawie Sprawozdania ze stanu KUL w roku akademickim 1936/37, Lublin [1937], s. 21.

b. d. - brak danych

Źródło: AU KUL, Biblioteki Zakładowe Wydziału Prawa i Nauk Społeczno-Ekonomicznych 19201939; Kancelaria Rektorska. Biblioteki Zakładowe. Biblioteki Zakładów Naukowych. Wydział Prawa i Nauk Społeczno-Ekonomicznych 1946-1950; Sprawozdanie ze stanu KUL w roku akademickim 1936/37, Lublin [1937], s. 21.

Dokładne dane dotyczące stanu zasobów bibliotek seminaryjnych są znane dla $1930 \mathrm{r}$. Wtedy też przeprowadzono skontrum, na podstawie którego wykazano braki książek: dla biblioteki ekonomicznej - 19 książek, a w przypadku biblioteki prawnej-37 publikacji ${ }^{54}$.

Do początku lat 30. XX w. liczebność księgozbiorów bibliotek Wydziału Prawa i Nauk Społeczno-Ekonomicznych nie przekroczyła tysiąca publikacji. Kolejna dekada przyniosła znaczący (co najmniej dwukrotny) wzrost liczby książek bibliotek seminaryjnych. W sierpniu 1939 r. Biblioteka Seminarium Ekonomicznego liczyła ponad 2.000 książek, a Biblioteka Seminarium Prawnego - 3.000 publikacji. Największy zasób miała Biblioteka Seminarium Polityki Społecznej, dzięki kilkutysięcznemu darowi ks. prof. A. Szymańskiego.

Przed wybuchem drugiej wojny światowej, liczebność księgozbioru wszystkich bibliotek seminaryjnych Wydziału Prawa i Nauk Społeczno-Ekonomicznych wyniosła ponad 9.000 publikacji. Natomiast suma księgozbiorów wszystkich bibliotek seminaryjnych, funkcjonujących na czterech wydziałach uniwersytetu,

${ }^{53}$ Zestawienia podawane według numerów inwentarza (nie woluminów) na miesiąc czerwiec lub lipiec.

${ }^{54}$ AU KUL, Biblioteki Zakładowe Wydziału Prawa i Nauk Społeczno-Ekonomicznych 19201939. Sprawozdanie z działalności kierownictwa Biblioteki Seminarium Prawno-Ekonomicznego KUL w okresie od 1 września 1930 do 1 lipca 1931. 
wynosiła ponad 20.000 woluminów ${ }^{55}$. Z kolei Biblioteka Główna KUL posiadała w tym czasie ponad 80.000 woluminów (łącznie ze zbiorami specjalnymi ${ }^{56}$.

Istnieją jednak nieścisłości w danych, gdyż w Sprawozdaniu ze stanu KUL w roku akademickim 1936/37 podano 4.500 publikacji jako liczbę zasobu księgozbioru biblioteki polityki społecznej, a dwa lata później liczba ta zmniejszyła się o około 400 prac. Być może różnica ta jest wynikiem błędu lub też - w 1937 r. podano również książki nieskatalogowane.

Biblioteki seminaryjne, oprócz druków zwartych, posiadały czasopisma. Biblioteki otrzymywały je albo w prenumeracie albo z darów. Wraz z upływem czasu, liczba tytułów czasopism wzrastała. Dla przykładu, na dzień 1 września 1931 r. Biblioteka Seminarium Ekonomicznego posiadała 17 tytułów czasopism, z czego 9 - stanowiły dary ${ }^{57}$. Około połowy trzeciej dekady XX w. Biblioteka Seminarium Ekonomicznego miała 21 tytułów czasopism, z czego 6 tytułów stanowiły periodyki obcojęzyczne: cztery niemieckojęzyczne (m.in. ,Zeitschrift für Nationalökonomie" 58 , „Weltwirtschaftliches Archiv" ${ }^{59}$ ) i dwa francuskie (,Revue d'Économie Politique" ${ }^{60}$, „Bulletin Statistique du Ministère des Finances"61 $)^{62}$. Polskie czasopisma były reprezentowane przez m.in. „Ekonomistę” ${ }^{63}$, „Przegląd Gospodarczy”64, „Polskę Gospodarczą"65, „Wiadomości Statystyczne”66, „Konjunkturę Gospodarczą" ${ }^{67}$ oraz „Rolnika Ekonomistę"68.

W tym czasie Biblioteka Seminarium Prawnego posiadała 23 tytuły periodyków, w tym pięć francuskich (m.in. „Revue Générale de Droit International

${ }^{55}$ Dzierzkowska, Biblioteka Główna Katolickiego Uniwersytetu Lubelskiego, s. 203.

${ }^{56}$ K. Wiśniowska, Kalendarium Biblioteki, ABMK, 23 (1971) s. 31.

${ }^{57}$ AU KUL, Biblioteki Zakładowe Wydziału Prawa i Nauk Społeczno-Ekonomicznych 19201939. Sprawozdanie z działalności kierownictwa Biblioteki Seminarium Prawno-Ekonomicznego KUL w okresie od 1 lipca 1931 do 15 czerwca 1932.

${ }^{58}$ „Zeitschrift für Nationalökonomie”, Wien 1930-1985.

${ }^{59}$ „Weltwirtschaftliches Archiv: Zeitschrift für Allgemeine und Spezielle Weltwirtschaftslehre”, Jena 1913-2002.

${ }^{60}$ „Revue d'Économie Politique”, Paris 1887-.

${ }^{61}$ „Bulletin Statistique du Ministère des Finances”, Varsovie 1924-1939.

${ }^{62}$ AU KUL, Biblioteki Zakładowe Wydziału Prawa i Nauk Społeczno-Ekonomicznych 19201939.

${ }^{63}$ „Ekonomista: kwartalnik poświęcony nauce i potrzebom życia”, Warszawa1901-.

${ }^{64}$ „Przegląd Gospodarczy: organ Centralnego Związku Polskiego Przemysłu, Górnictwa, Handlu i Finansów”, Warszawa 1920-1939.

${ }^{65}$ „Polska Gospodarcza: tygodnik wydawany przez Ministerstwo Przemysłu i Handlu przy współudziale Ministerstw: Skarbu, Rolnictwa oraz Komunikacji”, [red. nacz. W. Gieysztor, Cz. Peche], Warszawa 1930-1939.

${ }^{66}$ „Wiadomości Statystyczne Głównego Urzędu Statystycznego”, red. I. Weinfeld, S. Szulc, Warszawa 1923-1939, 1945-1951.

${ }^{67}$ „Konjunktura Gospodarcza: Wydawnictwo Instytutu Badania Konjunktur Gospodarczych i Cen”, Warszawa 1928-1939.

${ }^{68}$ „Rolnik Ekonomista: organ Związku Polskich Organizacyj Rolniczych”, red. A. Iwański, Warszawa 1926-1936. 
Public"69, „Journal du Droit International"70), dwa niemieckojęzyczne (m.in. „Zeitschrift für Öffentliches Recht”" ${ }^{\text {") }}$ i jeden angielskojęzyczny (The American Journal of International Law" $\left.{ }^{72}\right)^{73}$. Wśród polskich czasopism warto wymienić takie tytuły, jak: „Gazeta Administracji i Policji Państwowej”74, „Przegląd Prawa i Administracji”75, „Gazeta Sądowa Warszawska”"76, „Czasopismo Adwokatów Polskich”77, „Dziennik Ustaw Rzeczypospolitej Polskiej”78, „Orzecznictwo Sądów Polskich”79, „Zbiór Wyroków Najwyższego Trybunału Administracyjnego" $"$, „Ruch Prawniczy, Ekonomiczny i Socjologiczny”" .

Na koniec roku akademickiego 1935/1936 Biblioteka Seminarium Prawniczego liczyła już 25 tytułów czasopism, a Biblioteka Seminarium Ekonomicznego -23 periodyki, w tym 12 przesyłane były bezpłatnie ${ }^{82}$.

Należy podkreślić, że ze względu na złe warunki lokalowe Biblioteki Głównej oraz jej oddalenie od Uczelni, władze uniwersyteckie - od czasów rektora ks. C. Sokołowskiego (1924-1925) - położyły nacisk na rozwój bibliotek seminaryjnych. Wiele publikacji o charakterze źródłowym oraz podręczników zostało przeniesionych do księgozbiorów seminariów. Pomimo trudnej sytuacji finansowej uniwersytetu, biblioteki te lepiej rozwijały się niż Biblioteka Główna, która $\mathrm{w}$ tym okresie pełniła rolę drugoplanową w stosunku do bibliotek seminaryjnych ${ }^{83}$.

Po wybuchu II wojny światowej, w okresie od października do grudnia 1939 r. księgozbiory bibliotek seminaryjnych zostały częściowo zniszczone przez wojska niemieckie, które zajęły gmach KUL. Książki były palone w piecach. Utracono 1638 dzieł, co stanowiło około 4.000 woluminów. Zniszczeniu uległy wszystkie

${ }^{69}$ „Revue Générale de Droit International Public”, Paris 1894-.

${ }^{70}$ „Journal du Droit International”, Paris 1915-.

${ }^{71}$ „Zeitschrift für Öffentliches Recht”, Wien 1919-1944.

${ }^{72}$ „The American Journal of International Law”, [Washington] 1907-.

${ }^{73}$ AU KUL, Biblioteki Zakładowe Wydziału Prawa i Nauk Społeczno-Ekonomicznych 19201939.

74 „Gazeta Administracji i Policji Państwowej”, [red. E. Grabowiecki], Warszawa 1922-1935. Późniejszy tytuł: „Gazeta Administracji: dwutygodnik poświęcony prawu publicznemu oraz zagadnieniom administracji rządowej i samorządowej”, red. F. Kaufman, Warszawa 1936-1950.

${ }^{75}$ „Przegląd Prawa i Administracyi”, red. E. Till, B. Łoziński, Lwów 1892-1939.

${ }^{76}$ „Gazeta Sądowa Warszawska”, red. W. Prokopowicz, Warszawa 1873-1939.

77 „Czasopismo Adwokatów Polskich: organ Związku Adwokatów Polskich we Lwowie”, [red.

K. Argasiński], Lwów 1913-1914.

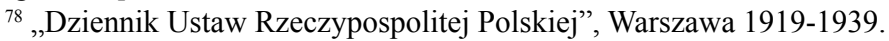

79 „Orzecznictwo Sądów Polskich”, red. T. Bujak, Warszawa 1921-1939.

${ }^{80}$ „Zbiór Wyroków Najwyższego Trybunału Administracyjnego. Dział A”, red. K. Bernaczek, Warszawa 1930-1939.

${ }^{81}$ „Ruch Prawniczy, Ekonomiczny i Socjologiczny: organ Wydziału Prawno-Ekonomicznego Uniwersytetu Poznańskiego poświęcony nauce i życiu prawnemu i gospodarczemu Rzeczypospolitej Polskiej”, Poznań 1925-1939.

${ }^{82}$ AU KUL, Biblioteki Zakładowe Wydziału Prawa i Nauk Społeczno-Ekonomicznych 19201939.

${ }^{83}$ Dzierzkowska, Biblioteka Główna Katolickiego Uniwersytetu Lubelskiego, s. 237. 
szafki katalogowe. Świadkami tych wydarzeń byli pracownicy uczelni, którzy zamieszkiwali w gmachu m.in. prof. I. Czuma ${ }^{84}$.

\section{Organizacja}

Nie ma szczegółowych danych dotyczących zasad funkcjonowania bibliotek w pierwszym dziesięcioleciu ich istnienia. Dokładniejsze informacje na temat działalności tych jednostek są znane z lat 30. XX w., a zawłaszcza dzięki Instrukcji dla bibliotekarza Seminarjum Wydziatu Prawa i Nauk Spoleczno-Ekonomicznych ${ }^{85}$. Zawarte są w niej szczegółowe przepisy dotyczące obowiązków i uprawnień bibliotekarza, księgozbiorów i korzystania z publikacji.

Zasady zarządzania bibliotekami normowały wewnętrzne regulaminy, opracowywane przez bibliotekarzy i stopniowo wprowadzane w kolejnych bibliotekach seminaryjnych. Na podstawie sprawozdania z działalności Biblioteki Seminarium Ekonomicznego za rok 1935/1936 wiadomo, że bibliotekarz Jerzy Malczewski, postulował zaprowadzenie Regulaminu dyżurów w celu sumiennego wypełniania obowiązków przez stypendystów, naniesienia koniecznych zmian w Regulaminie wewnętrznym Seminarium Ekonomicznym oraz opracowania Regulaminu uzupetniania księgozbiorów seminaryjnych ${ }^{86}$.

Pod koniec lat 30. XX w. przekazanie odpowiedzialności za majątek biblioteczny przez bibliotekarza odbywało się na podstawie protokołu zdawczo-odbiorczego. Zachował się protokół Biblioteki Seminarium Prawnego KUL z dnia 21 marca 1938 r. w którym bibliotekarz Witold Baliński przekazał powierzone mienie Stefanowi Pyśniakowi ${ }^{87}$. Inwentarz stanowił 10 szaf z książkami i czasopismami, biblioteka podręczna, 6 ksiąg inwentarzowych, 6 katalogów kartkowych oraz wykaz książek wypożyczonych, wykaz rachunków, zeszyty kontroli dyżurów, pieczątki biblioteki, klucze do szaf i biblioteki.

Wiadomo, że w latach 30. XX w. biblioteki seminaryjne generalnie były czynne przez sześć-osiem godzin dziennie. Godziny pracy były wywieszane na drzwiach biblioteki ${ }^{88}$. Dla przykładu, w roku akademickim 1932/1933 Biblioteka Seminarium Polityki Społecznej była czynna w godzinach 10.00-13.00 i 16.0019.00 $0^{89}$. Z kolei, w roku akademickim 1935/1936 Biblioteka Seminarium Prawnego była czynna od poniedziałku do soboty od 9.00 do 13.00 i z przerwą: od 15.00

${ }^{84}$ AU KUL, Kancelaria Rektorska. Biblioteki Zakładowe. Biblioteki Zakładów Naukowych. Wydział Prawa i Nauk Społeczno-Ekonomicznych 1946-1950.

${ }^{85}$ AU KUL, Biblioteki Zakładowe Wydziału Prawa i Nauk Społeczno-Ekonomicznych 19201939. Instrukcja dla bibliotekarza Seminarium Wydziału Prawa i Nauk Społeczno-Ekonomicznych.

${ }^{86}$ AU KUL, Biblioteki Zakładowe Wydziału Prawa i Nauk Społeczno-Ekonomicznych 19201939. Sprawozdanie z działalności Biblioteki Seminarium Ekonomicznego za okres od 1 sierpnia 1935 do 15 czerwca 1936.

${ }^{87}$ AU KUL, Biblioteki Zakładowe Wydziału Prawa i Nauk Społeczno-Ekonomicznych 19201939. Protokół przejęcia Biblioteki Seminarium Prawnego KUL z dnia 21 marca 1938.

${ }^{88}$ AU KUL, Biblioteki Zakładowe Wydziału Prawa i Nauk Społeczno-Ekonomicznych 19201939. Instrukcja dla bibliotekarza Seminarium Wydziału Prawa i Nauk Społeczno-Ekonomicznych.

${ }^{89}$ AU KUL, Biblioteki Zakładowe Wydziału Prawa i Nauk Społeczno-Ekonomicznych 19201939. Sprawozdanie Biblioteki Seminarium Polityki Społecznej KUL za rok akademicki 1932/33. 
do 20.00, a w czasie ferii w godz. 9.00-13.00 i 17.00-20.0090. W tym samym roku akademickim, Biblioteka Seminarium Ekonomicznego była otwarta od 9.00 do 13.00 i od 17.00 do 20.00, przy czym rano dyżurował bibliotekarz Seminarium Ekonomicznego, a po południu bibliotekarz Seminarium Prawnego. Od stycznia do czerwca 1936 r. bibliotekarzowi pomagali stypendyści w liczbie 6 osób. Pracowali oni po 6 godzin tygodniowo: od poniedziałku do soboty, czyli łącznie 36 godzin w godzinach popołudniowych. Biblioteka w okresach świątecznych: Bożego Narodzenia i Wielkiej Nocy pozostawała do dyspozycji czytelników w godzinach 9.00-13.00 i była obsługiwana przez bibliotekarza Seminarium Ekonomicznego, który wypożyczał również książki z Seminarium Prawnego ${ }^{91}$.

Do głównych obowiązków bibliotekarzy seminariów należało: katalogowanie książek i czasopism, udostępnianie książek i wypożyczanie do domu (za zgodą profesorów), udzielanie informacji, naprawa zniszczonych książek, prowadzenie rachunkowości, ustalanie dyżurów stypendystów oraz nadzór nad porządkiem w czytelni ${ }^{92}$.

Udostępnianie księgozbiorów (książek, czasopism i map) odbywało się po ich skatalogowaniu, czyli wpisaniu do inwentarzy poszczególnych seminariów. Księgozbiór seminarium ekonomicznego był podzielony na działy (ekonomii politycznej, polityki ekonomicznej i historii gospodarczej, geografii gospodarczej, skarbowości oraz statystyki) i oznaczony odpowiednimi literami. Publikacje były wpisywane do katalogu kartkowego: alfabetycznego i rzeczowego (z zastosowaniem systemu dziesiętnego $)^{93}$.

Korzystanie z książek seminaryjnych odbywało się na miejscu w czytelni, a udostępnianie na zewnątrz - za zgodą kierowników działu. Publikacje wypożyczano (maksymalnie 3 książki), po wypełnieniu rewersów, na okres dwóch tygodni, z możliwością prolongaty do czterech tygodni. Za przekroczenie terminu zwrotu czytelnik płacił 20 groszy za tydzień od każdej książki. Do domu nie wolno było wypożyczać podręczników i czasopism ${ }^{94}$.

Jeśli chodzi o zestawienia statystyczne dotyczące liczby użytkowników Bibliotek Wydziału Prawno-Ekonomicznego, to zachowały się dane z początku lat 30. XX wieku. W świetle sprawozdania bibliotekarza Konstantego Turowskiego, liczba czytelników w roku akademickim 1930/1931 wyniosła 1.706 osób,

${ }^{90}$ AU KUL, Biblioteki Zakładowe Wydziału Prawa i Nauk Społeczno-Ekonomicznych 19201939. Biblioteka Seminarium Prawnego. Sprawozdanie za rok 1935/1936.

${ }^{91}$ AU KUL, Biblioteki Zakładowe Wydziału Prawa i Nauk Społeczno-Ekonomicznych 19201939. Biblioteka Seminarium Prawnego. Sprawozdanie za rok 1935/1936; Sprawozdanie z działalności Biblioteki Seminarium Ekonomicznego za okres od 1 sierpnia 1935 do 15 czerwca 1936.

${ }^{92}$ AU KUL, Biblioteki Zakładowe Wydziału Prawa i Nauk Społeczno-Ekonomicznych 19201939. Instrukcja dla bibliotekarza Seminarium Wydziału Prawa i Nauk Społeczno-Ekonomicznych.

${ }^{93}$ AU KUL, Biblioteki Zakładowe Wydziału Prawa i Nauk Społeczno-Ekonomicznych 19201939. Sprawozdanie z działalności kierownictwa Biblioteki Seminarium Prawno-Ekonomicznego KUL w okresie od 1 września 1931 do 1 lipca 1932.

${ }^{94}$ AU KUL, Biblioteki Zakładowe Wydziału Prawa i Nauk Społeczno-Ekonomicznych 19201939. Instrukcja dla bibliotekarza Seminarium Wydziału Prawa i Nauk Społeczno-Ekonomicznych. 
a w kolejnym roku - 2.889 użytkowników ${ }^{95}$. Dla porównania w 1933 r. Bibliotekę Główną (zlokalizowaną przy ul. Dolnej Panny Marii) odwiedziło 8.638 osób ${ }^{96}$. Dokładne informacje dotyczące frekwencji czytelników biblioteki ekonomicznej, przynosi sprawozdanie biblioteczne za okres 1.08.1935-15.06.1936. To zestawienie ilustruje poniższy wykres.

Wykres nr 1. Frekwencja czytelników Biblioteki Seminarium Ekonomicznego w okresie 1.08.1935-15.06.1936.

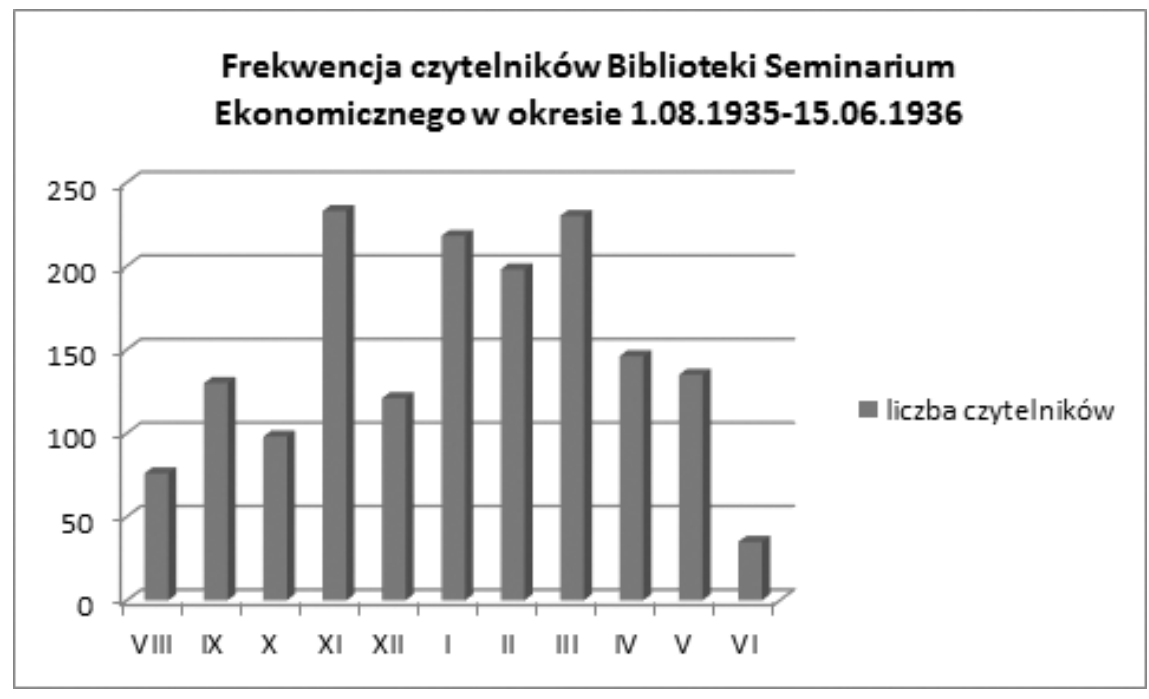

Źródło: AU KUL, Sprawozdanie z działalności Biblioteki Seminarium Ekonomicznego za okres od 1 sierpnia 1935 do 15 czerwca 1936.

Największa frekwencja w Bibliotekach Seminarium Ekonomicznego miała miejsce w trzech miesiącach: listopad, styczeń i marzec. Bibliotekę odwiedzało wtedy ponad dwustu czytelników dziennie. Przeciętna liczba czytelników wynosiła 147 osób dziennie. Należy podkreślić, że biblioteka cieszyła się bardzo dużą popularnością. W tym czasie na wydziale prawno-ekonomicznym uczyło się 878 studentów ${ }^{97}$.

W roku akademickim 1935/1936 przeciętna liczba osób korzystających z Biblioteki Seminarium Prawa wynosiła 40 osób, z czego połowę stanowili studenci pierwszego roku, a kolejne $20 \%$ przypadało na studentów czwartego roku, pozostałe $30 \%$ - słuchacze pozostałych lat prawa i inni studenci. W kolejnym roku akademickim 1936/1937 Bibliotekę Seminarium Prawa odwiedzało 30 osób dziennie.

${ }^{95}$ AU KUL, Biblioteki Zakładowe Wydziału Prawa i Nauk Społeczno-Ekonomicznych 19201939. Sprawozdanie z działalności kierownictwa Biblioteki Seminarium Prawno-Ekonomicznego KUL w okresie od 1 lipca 1931 do 15 czerwca 1932.

${ }_{96}$ Biblioteka Uniwersytecka Katolickiego Uniwersytetu Lubelskiego Jana Pawła II, Rkps 208A, Rękopisy Emilii Szeligi-Szeligowskiej, teczka II, k. 31.

${ }^{97}$ Sprawozdanie ze stanu KUL w roku akademickim 1935/36, Lublin [1936], s. 17. 
Natomiast, w świetle sprawozdania Biblioteki Seminarium Polityki Społecznej (za rok akademicki 1932/1933, liczba użytkowników, według sporządzającego sprawozdanie bibliotekarza, „była niska i wynosiła 100 osób”"98. Nie zostało jednak określone, za jaki okres czasu dotyczą przedstawione dane.

\section{Zakończenie}

W okresie dwudziestolecia międzywojennego, biblioteki seminaryjne istniejące na Wydziale Prawa i Nauk Społeczno-Ekonomicznych: prawna, ekonomiczna i polityki społecznej stanowiły podręczny warsztat naukowy dla pracowników naukowych i studentów Katolickiego Uniwersytetu Lubelskiego.

Ze względu na zły stan techniczny budynku Biblioteki Głównej, jej oddalenie od uczelni a także trudności finansowe uniwersytetu, Biblioteka Wydziału Prawa i Nauk Społeczno-Ekonomiczna, podobnie jak inne biblioteki seminaryjne, była właściwą bazą dydaktyczną do pracy naukowej. Władze uniwersytetu położyły nacisk na rozwój właśnie tych bibliotek, które pełniły rolę nadrzędną w stosunku do Biblioteki Głównej.

Księgozbiory bibliotek seminaryjnych były tworzone od chwili uruchomienia Wydziału. Zasób narastał stopniowo dzięki zakupom i darom. Do najważniejszych darowizn należały książki ofiarowane przez Bibliotekę Główną Uniwersytetu Lubelskiego i prof. A. Szymańskiego (księgozbiór przekazany Bibliotece Seminarium Polityki Społecznej) oraz wykładowców Wydziału Prawa i Nauk Społeczno-Ekonomicznego. Łącznie do dyspozycji pracowników i studentów tego Wydziału w 1939 roku było ponad 9.000 publikacji.

słowa kluczowe: Biblioteki Wydziału Prawa i Nauk Społeczno - Ekonomicznych Katolickiego Uniwersytetu Lubelskiego; Wydział Prawa i Nauk Społeczno - Ekonomicznych Katolickiego Uniwersytetu Lubelskiego; księgozbiór; biblioteka naukowa; dwudziestolecie międzywojenne

\section{BIBLIOGRAFIA}

\section{Źródla}

Archiwum Uniwersyteckie Katolickiego Uniwersytetu Lubelskiego Jana Pawła II (AU KUL)

Akta osobowe: Jan Amerek, sygn. PE 2966.

Akta osobowe: Jerzy Malczewski, sygn. PE 2804.

Akta osobowe: Kazimierz Osuchowski, sygn. PE 3114.

Akta osobowe: Konstanty Turowski, sygn. 1148 B.

Akta osobowe: ks. prof. Antoni Szymański, sygn. A-55.

Akta osobowe: Stefan Pyśniak, sygn. PNSE 4165.

Akta osobowe: Witold Baliński, sygn. PE 3032.

Biblioteki Zakładowe Wydziału Prawa i Nauk Społeczno-Ekonomicznych 1920-1939.

${ }^{98}$ AU KUL, Biblioteki Zakładowe Wydziału Prawa i Nauk Społeczno-Ekonomicznych 19201939. Sprawozdanie Biblioteki Seminarium Polityki Społecznej KUL za rok akademicki 1932/33. 
Kancelaria Rektorska. Biblioteki Zakładowe. Biblioteki Zakładów Naukowych. Wydział Prawa i Nauk Społeczno-Ekonomicznych 1946-1950.

Katalog książek oddanych do Biblioteki Seminarium Statystyczno-Ekonomicznego 4.05.1920-18.11.1938.

Katalog Seminarium Polityki Społecznej 12.01.1924-21.05.1933.

Biblioteka Uniwersytecka Katolickiego Uniwersytetu Lubelskiego Jana Pawła II (BU KUL)

Rękopisy Emilii Szeligi-Szeligowskiej, teczka II, Rkps 208A.

\section{Opracowania}

Bogusz Magdalena, Miszczuk Andrzej, Lubelskie akademickie środowisko ekonomistów w okresie międzywojennym, „Chrześcijanin w Świecie”, 19 (1987) nr 4 (163), s. 1631.

Dzierzkowska Danuta, Biblioteka Główna Katolickiego Uniwersytetu Lubelskiego 19181939, „Archiwa, Biblioteki i Muzea Kościelne”, 8 (1964) s. 187-242.

Karolewicz Grażyna, Geneza Katolickiego Uniwersytetu Lubelskiego, w: Katolicki Uniwersytet Lubelski. Wybrane zagadnienia z dziejów Uczelni, red. G. Karolewicz, M. Zahajkiewicz, Z. Zieliński, Lublin 1992, s. 47-70.

Karolewicz Grażyna, Nauczyciele akademiccy Katolickiego Uniwersytetu Lubelskiego w okresie międzywojennym, t. 1, Lublin 1996.

Karolewicz Grażyna, Nauczyciele akademiccy Katolickiego Uniwersytetu Lubelskiego w okresie międzywojennym, t. 2, Biogramy, Lublin 1996.

Karolewicz Grażyna, Środowisko naukowe KUL w okresie międzywojennym, w: Katolicki Uniwersytet Lubelski. Wybrane zagadnienia z dziejów Uczelni, red. G. Karolewicz, M. Zahajkiewicz, Z. Zieliński, Lublin 1992, s. 115-153.

Skład osobowy. Spis wykładów i instytucji Katolickiego Uniwersytetu Lubelskiego w roku akad. 1936/1937, Lublin [1936].

Skład osobowy. Spis wykładów i instytucji Katolickiego Uniwersytetu Lubelskiego w roku akad. 1937/1938, Lublin [1937].

Skład osobowy. Spis wykładów i instytucji Katolickiego Uniwersytetu Lubelskiego w roku akad. 1938/1939, Lublin [1938].

Spis wykładów i wykaz instytucyj uniwersyteckich. Pótrocze zimowe 1918/1919, Lublin 1919.

Sprawozdanie ze stanu KUL w roku akademickim 1935/36, Lublin [1936].

Sprawozdanie ze stanu KUL w roku akademickim 1936/37, Lublin [1937].

Sprawozdanie ze stanu KUL w roku akademickim 1937/38, Lublin [1938].

Stanowski Adam, Spis wykładowców 1918-1939, w: Księga Jubileuszowa 50-lecia Katolickiego Uniwersytetu Lubelskiego, Lublin 1969, s. 105-118.

Strzeszewski Czesław, Ks. Antoni Szymański jako profesor i rektor Katolickiego Uniwersytetu Lubelskiego, „Zeszyty Naukowe KUL”, 5 (1962), nr 3 (19), s. 103-114.

Wiśniowska Kazimiera, Kalendarium Biblioteki, „Archiwa, Biblioteki i Muzea Kościelne", 23 (1971) s. 29-43.

Wojtkowski Andrzej, Katolicki Uniwersytet Lubelski 1918-1944, w: Księga Jubileuszowa 50-lecia Katolickiego Uniwersytetu Lubelskiego, Lublin 1969, s. 21-104. 


\title{
THE LIBRARIES OF THE FACULTY OF LAW AND SOCIAL-ECONOMIC SCIENCES KUL IN THE PERIOD OF THE SECOND POLISH REPUBLIC
}

\begin{abstract}
Summary
During the interwar period at the Faculty of Law and Social-Economic Sciences of the Catholic University of Lublin, there were three main sectional libraries: legal, economic and social. In these libraries there were book collections, also referred to as libraries, assigned to a particular seminar. They were treated as research aid for employees and students. Initially, they were supervised by professors, who decided on the shape of the collection as well as the selection of library staff. Over time, there appeared a position of librarian who managed the collections of all the seminary libraries. In the 1930s librarians were assigned to each section separately; and they were responsible, among others, for cataloguing books and periodicals, making the collection available, providing research information, repairing damaged books, doing bookkeeping and arranging duty hours for scholarship holders. Seminar book collections increased as new books were bought and donated. The most important donations were books offered by the Main Library of the University of Lublin and Professor A. Szymański, a lecturer from the Faculty of Law and Social-Economic Sciences.

Keywords: the libraries of the Faculty of Law and Social-Economic Sciences at the Catholic University of Lublin; the Faculty of Law and Social-Economic Sciences at the Catholic University of Lublin; a book collection; a research library; the interwar period
\end{abstract}

